\title{
Dossiê/Dossier/Dosier
}

\section{Produção de conhecimentos, difusão e ensino na (e da) História da Educação}

\author{
Knowledge production, dissemination, and teaching in (and of) \\ History of Education
}

Producción de conocimientos, difusión y enseñanza en la (y de la) Historia de la Educación

\author{
ORGANIZAÇÃO \\ DENICE BARBARA CATANI ${ }^{1}$; DÉCIO GATTI JÚNIOR ${ }^{2}$
}

\section{Apresentação}

Sob a designação geral "Produção de conhecimentos, difusão e ensino na (e da) História da Educação", este dossiê tem o propósito de compreender processos de produção e de ensino do conhecimento histórico-educacional mediante o exame de casos específicos, do recurso a fontes e métodos diversos, bem como da experiência do ensino.

Os seis artigos reunidos retomam e analisam, entre outros aspectos, em especial, a utilização da legislação e dos manuais de ensino situando a discussão a partir de estudos desenvolvidos acerca de situações determinadas como a educação no Maranhão na Primeira República e a elaboração de manuais escolares e os sentidos por eles assumidos no campo educacional, em São Paulo, no período entre as décadas de 1940 e 1950. Características dos processos de autoria e legitimação dos manuais são objeto de atenção.

${ }^{1}$ Doutora em Educação pela Faculdade de Educação da Universidade de São Paulo (Feusp). Professora Titular Aposentada da Feusp. Bolsista de Produtividade em Pesquisa do CNPq (Nível 1B). E-mail: dbcat@usp.br

${ }^{2}$ Doutor em Educação: História e Filosofia da Educação pela Pontifícia Universidade Católica de São Paulo, com estágio de pós-doutorado concluído na Faculdade de Educação da Universidade de São Paulo. Professor Titular de História da Educação da Universidade Federal de Uberlândia. Bolsista de Produtividade em Pesquisa do CNPq (Nível 1C). Beneficiário do Programa Pesquisador Mineiro da Fapemig. E-mail: degatti@ufu.br 
Também se confere lugar de destaque para as potencialidades da legislação (e de diversas outras fontes) no confronto entre as proposições oficiais e a concretização de práticas na vida escolar, a partir da análise da situação do ensino de História da Educação em Minas Gerais constatando o baixo nível de correspondência entre prescrições e realizações no ensino.

Questões ligadas à produção do conhecimento histórico educacional e suas configurações em países (como Portugal, França e Espanha), cujas relações com o Brasil têm sido marcantes, são o ponto de partida para a discussão sobre o trânsito de modos de interpretação, escolhas teóricas e recurso a fontes que predominaram entre nós desde a década de 1970.

Os textos em seu conjunto evidenciam a preocupação com as possibilidades de concorrer para a história do ensino, da produção de conhecimentos, das escolas e da profissão docente. As potencialidades e limites dos diferentes materiais são problematizados em cada um dos trabalhos bem como o são as questões relativas às experiências de identificação, sistematização, disponibilização e ensino.

Desse modo, é possível afirmar que os artigos reunidos nesse dossiê se caracterizam de forma convergente ao se ancorar, cada um deles, em uma investigação específica de objeto e periodização autônomos e realizar, simultaneamente, incursões metodológicas que explicitam e debatem o potencial de fontes e métodos exemplificando marcas teóricas e enquadramentos diversos que mostram modalidades de construção de interpretações em História da Educação.

$\mathrm{O}$ artigo que abre o dossiê, intitula-se "A escrita da História da Educação: distâncias e proximidades na apropriação de fontes e métodos no caso das produções de Portugal, França, Espanha e Brasil”. Ele foi redigido por Denice Barbara Catani, da Universidade de São Paulo, como uma retomada de alguns resultados obtidos em investigação realizada sobre a produção de conhecimentos na área dos estudos educacionais e, em especial, sobre a produção dos estudos da História da Educação no Brasil. Para tanto, a autora recorreu à pesquisa dos processos que permitiram a construção e renovação de matrizes interpretativas a partir do exame da produção da área em países que sabidamente estabeleceram, nas últimas décadas, importantes relações acadêmicas com o nosso país, isto é França, Espanha e Portugal. Indicam-se, assim, as relações entre as transformações da escrita histórico educacional no Brasil e nos países citados atentando especialmente para as apropriações decorrentes de intercâmbios, deslocamentos e viagens dos conhecimentos em perspectiva comparada.

Em seguida, Anamaria Gonçalves Bueno de Freitas, da Universidade Federal de Sergipe, no texto intitulado "Fontes para a difusão da didática moderna no ensino da Língua Portuguesa: os manuais do Ensino Ginasial e a autoria docente nas décadas de 1940 e 1950", relatou resultados de investigação que mobilizou como fontes prioritárias os manuais de língua portuguesa para as séries ginasiais, editados nas décadas de 1940 e 1950, de autoria de professores paulistas, que pregava o aprendizado da gramática a partir de textos literários. A coleção "Páginas Floridas", de Francisco Silveira Bueno, editada pela Livraria Acadêmica, Saraiva e Cia e a "Coleção Didática do Brasil - Série Ginasial- Português", assinada por Aída Costa foram selecionadas como exemplares representativos de compreensão da circulação de novos padrões didáticos por professores-autores que ocuparam posições relevantes no campo educacional paulista e mobilizaram diferentes estratégias. A pretensão do estudo foi contribuir com a História da Profissão Docente, e com a História das Disciplinas Escolares ao desvendar a trajetória dos referidos autores, que difundiram o ensino de português e literatura, a partir de coleções, que tiveram circulação nacional. 
Cesar Augusto Castro, da Universidade Federal do Maranhão, redigiu o artigo intitulado "A legislação como fonte para a História da Instrução Primária maranhense", no qual defendeu que a legislação educacional é uma importante ferramenta de investigação do campo da História da Educação por possibilitar uma ampla e fértil compreensão do movimento educativo em determinado tempo e lugar. $\mathrm{O}$ autor buscou entender o uso dessa fonte como recurso para a pesquisa sobre a instrução primária maranhense nas últimas décadas do período imperial e no início do período republicano, por meio da discussão dos processos econômicos, políticos, sociais que contribuíram para a criação e expansão das instituições escolares e as várias reformas educativas que objetivaram o desenvolvimento do Maranhão por meio da instrução.

Em seguida, Joaquim Pintassilgo e Carlos Beato, do Instituto de Educação da Universidade de Lisboa, redigiram o artigo que intitularam "Balanço da produção recente no campo da História das Disciplinas Escolares: o exemplo das teses de doutoramento (Portugal, 2005-2015)", no qual realizaram um balanço da produção portuguesa recente em História da Educação, tomando como exemplo as teses de doutoramento passíveis de inserção no campo específico da História das Disciplinas Escolares, para o que, selecionaram o período delimitado pelos anos de 2005 e 2015. Afirmam que a História das Disciplinas Escolares é um campo consolidado no interior da investigação histórico-educativa que possui uma fundamentação teórica sólida, um conjunto diversificado de fontes e uma certa tradição de pesquisa, no que se refere aos procedimentos metodológicos e aos fundamentos teóricos e conceituais. Em um campo que atingiu uma certa estabilidade, e que podia correr algum risco de estagnação, os autores procuraram identificar os desafios que lhe estão a ser lançados, as abordagens que procuram renovar e as tendências que se abrem à investigação futura, assumindo a especificidade, mas, também, a exemplaridade de que se reveste este campo particular no conjunto da pesquisa em História da Educação.

Em “O Ensino de História da Educação no Brasil: fontes e métodos de pesquisa”, Décio Gatti Júnior, da Universidade Federal de Uberlândia, apresenta os avanços na pesquisa sobre o ensino de História da Educação em Minas Gerais, particularmente, com a apresentação de aspectos de uma trajetória coletiva e pessoal de busca de entendimento do "pré-curso" e dos percursos da disciplina História da Educação no Brasil, particularmente, em Minas Gerais, mas, também, como poderá ser percebido no texto do artigo, em São Paulo. No texto abordam-se os aspectos biográficos da entrada do pesquisador nesta temática da História Disciplinar da História da Educação. Depois, apresenta-se uma breve reflexão teóricometodológica e, por fím, há uma exposição sucinta dos resultados alcançados em investigações sob os cuidados do autor, diretamente, a partir dos projetos de pesquisa que têm desenvolvido e, indiretamente, especialmente nas orientações de iniciação científica, de mestrado e de doutorado que foram levadas a cabo nos últimos anos.

$\mathrm{O}$ dossiê termina com o texto intitulado "O exercicio docente universitario na materia 'Historia da educación'”, escrito por Antón Costa Rico, da Universidade de Santiago de Compostela, com abordagem direta da questão do ensino da disciplina História da Educação. Parte de uma pergunta central: -- Com qual História da Educação formar o nosso aluno universitário na atualidade? Para o autor, a resposta envolve a formação de um habitus histórico-educativo e os cenários específicos de formação pedagógica. 